\title{
UTILIZATION OF SOIL CONSERVATION PRACTICES AMONG ROOT AND TUBER FARMERS IN OYUN LOCAL GOVERNMENT AREA OF KWARA STATE, NIGERIA
}

\author{
Oladipo, F.O.*, Bolarin, O., Daudu, A.K., Kayode, A.O and Awoyele, P.O \\ Department of Agricultural Extension and Rural Development, \\ University of Ilorin, llorin, Nigeria \\ *Correspondence author: felixoladipo5@gmail.com
}

\begin{abstract}
One of the main reasons for the crop failure is underestimating the importance of soil status thereby causing mismanagement of the soil with inappropriate farming practices. This study therefore, assessed the soil conservation practices among root and tuber crop farmers in Oyun Local Government area of Kwara State, Nigeria. A two stage sampling technique was employed to select a total of 160 respondents used for the study. Data were collected and analysed using both descriptive and inferential statistics. The findings of the study revealed that the mean age of the respondents was 45.4 years with majority (69.4\%) being male and about half (50.0\%) had one form of formal education or another. Findings showed strong positive perception towards soil conservation practices using beneficial statement such as

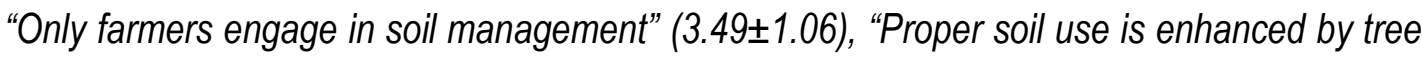
planting" (3.81 \pm 0.83$)$. Results showed that among the respondents mixed cropping (2.35 \pm 0.59$)$, conservation tillage $(2.26 \pm 0.77)$ and bush fallowing $(2.21 \pm 0.74)$ were always used and ranked 1 st, $2^{\text {nd }}$ and $3^{\text {rd }}$ respectively. There were positive and significant relationship between respondents educational level $(r=0.089, p=0.000)$ and household size $(r=0.012$, $p=0.000$ ) and their extent of usage of soil conservation practices at $5 \%$ level of significance. The study concluded that soil conservation practices were always used by root and tuber crop farmers and their perception were also positive towards it. It is recommended that root and tuber expansion programme should be strengthened and expanded to other communities that have not benefited from the programme.
\end{abstract}

Key words: Soil management practices, Utilization, Root and Tuber Crops, Farmers 


\section{INTRODUCTION}

One of the unique characteristics of rural communities in many developing countries across the world are the total dependence on agriculture for their livelihood. Therefore, since almost all rural households depend directly or indirectly on agriculture and given the large contribution of the sector to the overall economy agriculture is a key component of growth (IFPRI, 2007). Of the projected increase in world population of about 3 billion between 2008 and 2050, about half of it may occur in Africa where soil resources are already under great stress. The agrarian stagnation, plaguing food security in sub-Saharan Africa (SSA) since the early 1970s, may exacerbate with the projected climate change along with the attendant increase in risks of soil and environmental degradation (Birte et al., 2008). For example, the Nigerian population has increased from 115 million in 1991 to 140 million in 2006 (Federal Republic of Nigeria, 2007).

Root and tuber crops are second only in importance to cereals as a global source of carbohydrates. They also provide some minerals and essential vitamins, although a proportion of the minerals and vitamins may be lost during processing as, for example, in the case of cassava. The quantity and quality of the protein in starchy staples are variable and relatively low on a fresh weight basis but compare favorably with some cereals on a dry weight basis. In most traditional diets vegetable soups, meat, groundnuts, grain legumes and fish are good sources of protein and are frequently used to supplement root crops and compensate for their protein deficiencies. It is better for the root and tuber crop farmers to concentrate on soil conservation methods that would increase the land productive capacity rather than the methods that would increase crop productivity within a short time and thereafter causes havoc to the soil. In the olden days, shifting cultivation and bush fallowing systems were the best methods of conserving soil fertility as a result of vast land available for crop production. Shifting cultivation is fast dwindling especially in north central Nigeria as a result of the different ways lands are being used; road construction, land excavation for different purposes and yearly cultivation of land without rest are the various ways in which nutrients are being mined with little attention in replacing the nutrients mined and depleted (FAO, 2013).

One of the most severe threats to the sustainability of agricultural crops production in Nigeria is declining productivity as a result of the loss of soil fertility. Soils in Nigeria suffer deficiency common to the soils in the tropic such as a low percentage organic matter and nitrogen, 
shallow depth and high acidity which predispose about $63 \%$ of agricultural soils in Nigeria to low productivity (Lekwa and Whiteside, 1996). There are different ways in which farmers till the lands. Some of the methods include selective and total felling of trees, controlled and uncontrolled bush burning, conventional and manual tillage, different planting and harvesting methods and judicious and injudicious application of fertilizers (FAO, 2013). The stated methods and hosts of others not mentioned either adds nutrients to the soil or cause soil degradation. The problem of land scarcity for food crop production is aggravated by rapid urbanization, conversion to nonagricultural uses, and severe soil degradation (Birte et al., 2008). Overuse of soils causes acidification, salinization or other chemical soil contamination. Soil Scientists need to adapt a positive approach to natural resources management. The soils need to be preserved to avert future hunger strike. Crop production depends largely on soil and is affected greatly by the quality of that soil. Soil quality also plays a role in the environmental effects of crop production. Soil management involves actions by land managers that affect soil quality and productivity and alter soils effects on environmental quality. Examples of these actions include land use or cropping pattern, type and extent of tillage, amount of cover or residue left on the soil and use of conservation buffers and structures. Soil as a plant growing medium is the key resource in crop production. Soil supports all the processes that plant needs to grow.

Soil conservation is a combination of all methods of management and land use that safeguard the soil against depletion or deterioration by natural or man-induced factors (Acton et al., 2013). One of the main causes of soil degradation identified in various parts of Africa by the Food and Agriculture Organization of the United Nations (FAO, 2013) is the practice of inappropriate methods of soil preparation and tillage. The soil naturally replenishes itself when used properly. In an attempt to maintain optimum crop productivity, farmers are encouraged to adopt different production technologies that would conserve the soil. In relation to this, Onwudike et al. (2016) suggested adoption of many strategies aimed at improving soil productivity and crop yield. However, there is no known research that assesses the cropping practices that affect soil fertility especially in the study area (Daudu et al., 2016). Therefore, the general objective of this study was to assess the soil conservation practices used among root and tuber crop farmers in Oyun Local Government area of Kwara State, Nigeria. The specif objectives were to:

a. ascertain the socio economic characteristics of roots and tuber crop farmers;

b. assess the farmer's perception towards soil conservation practices; and 
c. determine the extent of use of soil conservation practices by root and tuber crop farmers in the study area.

\section{Hypothesis}

$\mathrm{H}_{01}$ : There is no significant relationship between some selected socio economic characteristics of the root and tuber crop farmers and their extent of usage of soil conservation practices.

\section{METHODOLOGY}

This study was conducted in Oyun Local Government Area of Kwara State, Nigeria. The headquarters is llemona. It is located in the south-eastern part of Kwara State with a land area of 650 square kilometres. It has a population of 94,253 at the 2006 census (NPC, 2006), consisting of Yoruba ethnic group. The two main climatic conditions are dry and wet seasons. The natural vegetation of the area comprises wooded and rain forest savannah. Major land forms in the state are plains, undulating hills and valleys. Agriculture is the main stay of the economy and the area is known for the cultivation of the following crops, sweet potatoes, maize, cassava, yam, groundnuts and vegetables.

The population of the study comprised all roots and tubers crop farmers in Oyun Local Government Area of Kwara state, Nigeria. Oyun local government was purposively selected based on their participation in Roots and Tubers Expansion Programme (RTEP) of Kwara State Agricultural Programme. Eight (8) villages in the local government were randomly selected and twenty (20) root and tuber crop farmers were randomly selected from each village making a total sample size of 160 . Data collected were through structured interview and questionnaire and analysed with descriptive statistics such as frequency, percentages, mean, standard deviation and charts. Pearson Product Moment Correlation was used to make deductions from the study.

\section{RESULTS AND DISCUSSION}

\section{Socioeconomic characteristics of the respondents}

Results in Figure 1, revealed that the mean age of root and tuber crop farmers was 45.4 years with most $(46.3 \%)$ falling within the age range of $41-50$ years old. This suggests that an average root and tubers crop farmers in the study area were still in their active age. The results in Figure 2 showed that majority (69.4\%) of respondents were males, indicating that 
male were more involved in the roots and tubers expansion programme than their female counterparts that uses soil conservation practices in the study area.

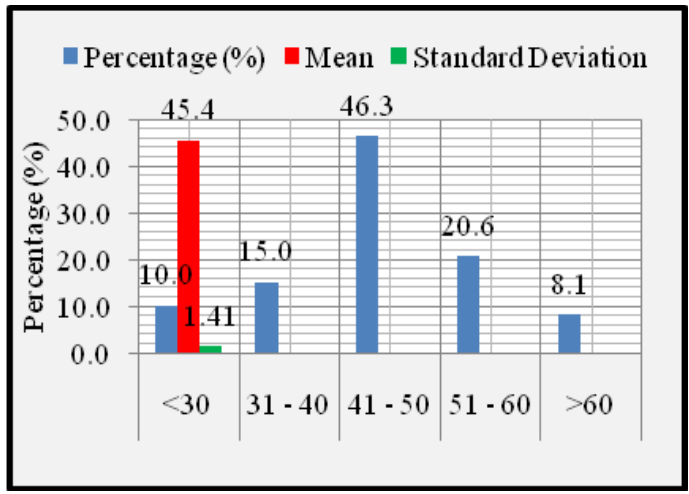

Fig. 1: Age of the respondents

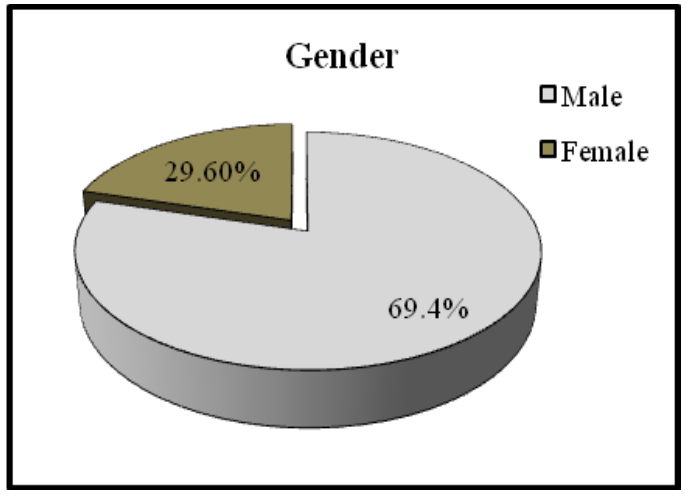

Fig. 2: Gender of the respondents

Source: Field survey, 2016

Furthermore, findings from the study showed that half of the respondents $(50 \%)$ had no formal education, $37.5 \%, 10.60 \%$ and $1.90 \%$ completed their primary, secondary and tertiary education respectively (See Fig. 3). This collaborates with the findings of Adediran (2008) and Adefalu et al. (2011) that majority of rural work force have secondary school education, the fact that some of the respondents had tertiary education is because some tertiary institutions like college of health technology, federal polytechnic were actually close to them and affordable.

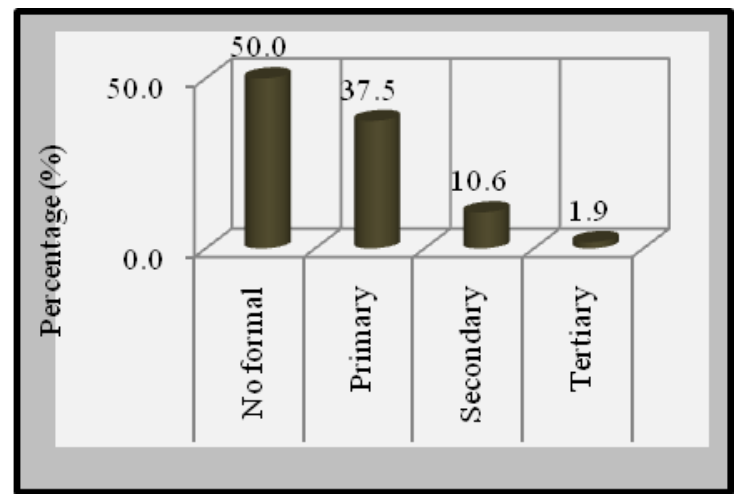

Fig. 3: Educational level of the respondents

Source: Field survey, 2016 
Results in Figure 4 revealed that the mean household size of the respondents was 5 person. This figure is in consonance with 5 people per rural household size as established by the National Bureau of Statistics (NBS, 2006). That is, most of the rural farmers had household size ranging from five to ten, indicating that the farmers would have access to family labour needed for producing root and tuber crop, because the household is the major source of labour in rural communities (Mendola, 2007). Also, further results in Figure 4 showed that about $29.0 \%$ hired labour, $34.4 \%$ used family labour, $8.7 \%$ used the types of labour together. Figure 4 revealed that some of the respondents engaged in secondary occupation like Teaching (16.9\%), Trading (33.8\%), Civil Service (28.1\%), Okada riding (11.2\%) and others $(10 \%)$ in other to meet their other daily need.

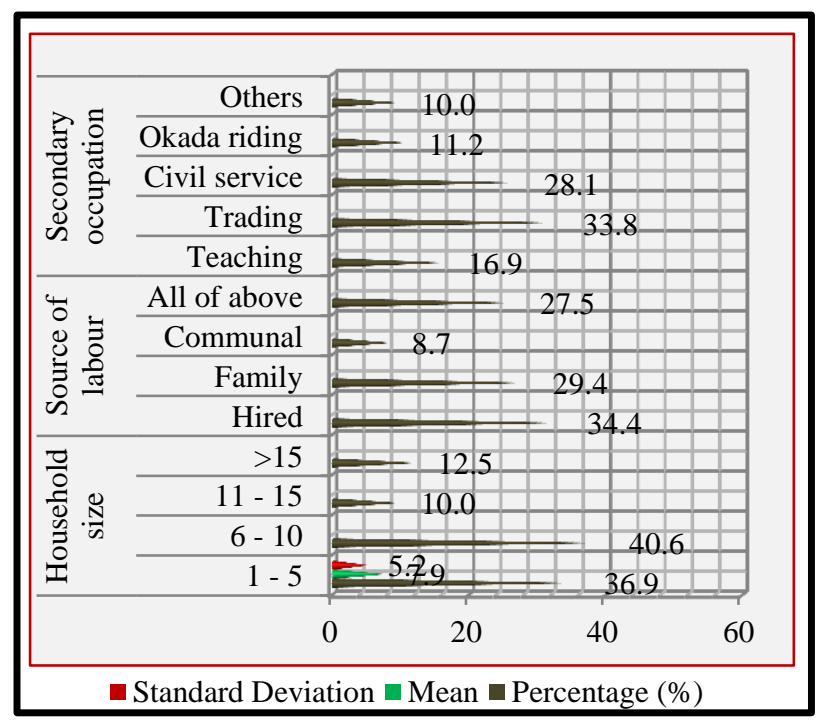

Fig. 4: Household size, source of labour and secondary occupation of the respondents Source: Field survey, 2016

\section{Perception of respondents towards soil conservation practices}

The result on table 1 presents the distribution of respondents according to their perception towards soil conservation practices. The farmers' perception towards soil conservation practices was revealed based on their agreement and disagreement with a number of statements. Findings in Table 1 revealed that respondents' showed strong positive perception towards soil conservation practices using beneficial statement such as "Only farmers engage in soil management" (3.49 \pm 1.06$)$, "Proper soil use is enhanced by tree planting" $(3.81 \pm 0.83)$, 
"Soil texture can be improved by crop rotation" (3.64 \pm 1.15$)$, "Water logging can be prevented by drainage" $(3.94 \pm 1.04)$ respectively. Also, "Future generation will benefit from soil conservation" (4.55 \pm 0.73$)$ and "Application of manure increases soil fertility" (3.96 \pm 0.95$)$. Crop rotation enhances rational use of the land, assures steady high yields and permits greater diversification. This is because different crops are planted, tilled and harvested at different times and agricultural work is spread out more evenly over the year. These findings tally with those observed by Bagheri (2010) where potato farmers had a positive perception about the role of crop rotation in Ardabil Province of Iran. The results showed that greater proportion of the respondents have positive attitude towards the use of soil conservation practices.

Table 1: Perception of respondents towards soil conservation practices

\begin{tabular}{|c|c|c|c|c|c|c|}
\hline Perception statement & $\begin{array}{l}\text { Strongly } \\
\text { Agree }\end{array}$ & Agree & Disagree & $\begin{array}{l}\text { Strongly } \\
\text { disagree }\end{array}$ & Undecided & $\begin{array}{l}\text { Mean } \\
( \pm S D)\end{array}$ \\
\hline $\begin{array}{l}\text { Only farmers engage in } \\
\text { soil management }\end{array}$ & $27(16.9)$ & $63(39.4)$ & $34(21.2)$ & $33(20.6)$ & $3(1.9)$ & $3.49 \pm 1.06$ \\
\hline $\begin{array}{l}\text { Proper soil use is } \\
\text { enhanced by tree planting }\end{array}$ & $33(20.6)$ & $72(45.0)$ & $46(28.8)$ & $9(5.6)$ & 0 & $3.81 \pm 0.83$ \\
\hline $\begin{array}{l}\text { Application of manure } \\
\text { increases soil fertility }\end{array}$ & $41(25.6)$ & $90(56.2)$ & $18(11.2)$ & $3(1.9)$ & $8(5.0)$ & $3.96 \pm 0.95$ \\
\hline $\begin{array}{l}\text { Soil texture can be } \\
\text { improved by crop rotation }\end{array}$ & $29(18.1)$ & $83(51.9)$ & $28(17.6)$ & $1(0.6)$ & 19(11.9) & $3.64 \pm 1.15$ \\
\hline $\begin{array}{l}\text { Water logging can be } \\
\text { prevented by drainage }\end{array}$ & $54(33.8)$ & $62(38.8)$ & $31(19.4)$ & $6(3.8)$ & $7(4.4)$ & $3.94 \pm 1.04$ \\
\hline $\begin{array}{l}\text { Additional information } \\
\text { would cause farmers to } \\
\text { engage in more soil } \\
\text { management activities }\end{array}$ & $45(28.1)$ & $96(60.0)$ & $13(8.1)$ & $5(3.1)$ & $1(0.6)$ & $4.12 \pm 0.73$ \\
\hline $\begin{array}{lll}\text { Future generation } & \text { will } \\
\text { benefit from } & \text { soil } \\
\text { management } & \end{array}$ & $100(62.5)$ & $55(34.4)$ & $1(0.6)$ & $1(0.6)$ & $3(1.9)$ & $4.55 \pm 0.73$ \\
\hline
\end{tabular}

Source: Field survey, 2016

\section{Extent of usage of soil conservation practices by respondents}

The results in Table 2 revealed the extent of usage of soil conservation among root and tubers crop farmers in the study area using mean scores and standard deviation to rate the 
respondents' responses. For this study, any mean score of 2 and above was regarded as "Used", while mean score less than 2 regarded as "Not used". Results showed that among the respondents mixed cropping (2.35 \pm 0.59$)$, conservation tillage $(2.26 \pm 0.77)$, bush fallowing $(2.21 \pm 0.74)$, organic manure $(2.19 \pm 0.62)$, crop rotation $(2.16 \pm 0.48)$ and cover cropping $(2.05 \pm 0.54)$ were always used and ranked 1 st $, 2^{\text {nd }}, 3^{\text {rd }}, 4^{\text {th }}, 5^{\text {th }}$ and $6^{\text {th }}$ respectively. Also, the respondents who never used agro-forestry as means of conserving and preserving soil nutrients $(1.58 \pm 0.79)$ and ranked $7^{\text {th }}$ in the study area.

Table 2: Extent of usage of soil conservation practices by the respondents

\begin{tabular}{|c|c|c|c|c|c|c|}
\hline $\begin{array}{l}\text { Soil Conservation } \\
\text { Practices }\end{array}$ & $\begin{array}{l}\text { Never } \\
\text { used } \\
60.6\end{array}$ & $\begin{array}{l}\text { Occasionally } \\
\text { used } \\
18.8\end{array}$ & $\begin{array}{l}\text { Alway } \\
\text { s used } \\
20.6\end{array}$ & $\begin{array}{l}\text { Mean } \\
( \pm S D) \\
1.58 \pm 0.3\end{array}$ & Ranking & Decision \\
\hline Agro-forestry & & & & 9 & 7 & Never used \\
\hline & 5.0 & 20.6 & 74.4 & $2.16 \pm 0.6$ & 5 & \\
\hline Crop rotation & & & & 8 & & Used \\
\hline & 11.9 & 16.9 & 71.2 & $2.05 \pm 0.5$ & 6 & \\
\hline Cover cropping & 5.6 & 40.6 & 53.8 & $\begin{array}{l}4 \\
2.35 \pm 0.5\end{array}$ & 1 & Used \\
\hline Organic manure & 20.0 & 46.2 & 33.8 & $\begin{array}{l}9 \\
2.26 \pm 0.7\end{array}$ & 2 & Used \\
\hline Conservation tillage & 11.2 & 30.6 & 58.1 & $\begin{array}{l}7 \\
2.19 \pm 0.6\end{array}$ & 4 & Used \\
\hline Mixed cropping & 18.1 & 37.5 & 43.8 & $\begin{array}{l}2 \\
2.21 \pm 0.7\end{array}$ & 3 & Used \\
\hline Bush fallowing & & & & 4 & & Used \\
\hline
\end{tabular}

Source: Field survey, 2016

\section{Hypothesis}

Table 3 present the results of correlation analysis showing the relationship between the selected socioeconomic characteristics and the extent of usage of soil conservation practices among root and tuber crop farmers in the study area. There were positive and significant relationship between respondents educational level $(r=0.089, p=0.000)$ and household size $(r=0.012, p=0.000)$ and their extent of usage of soil conservation practices at $5 \%$ level of significance. This suggests that as the educational level and household size of the 
respondents increases the extent of usage of soil conservation practices among the root and tuber farmers would also increase. This conforms to the findings of (Daudu, 2016), that the higher the educational status of the farmers the higher their likelihood to be involved in soil fertility management practices. However, this finding is contrary to the findings of Matanmi et al. (2011) where no significant relationship was found between socio economic characteristics of respondents and the level of usage of new technology given to farmers. This could be attributed to the fact that education increases human understanding, knowledge and capacity to acquire skills.

Table 3: Results of correlation analysis showing the relationship between some selected socioeconomic characteristics of root and tuber crop farmers' and their extent of usage of soil conservation practices

\begin{tabular}{lcl}
\hline Variables & $\begin{array}{l}\text { Female } \\
\text { r-value }\end{array}$ & p-value \\
\hline Age & 0.3620 & 0.587 \\
Education & $0.089^{* *}$ & 0.000 \\
Household size & $0.012^{* *}$ & 0.000 \\
Source of labour & 0.3690 & 0.784 \\
\hline${ }^{* *}$ Correlation significant at 0.05 level (2-tailed)
\end{tabular}

Source: Field survey, 2016

\section{CONCLUSION}

From the findings of this study it could be concluded that, soil conservation practices were always used by root and tuber crop farmers and their perception was also positive towards it. Educational level and household size also had significant positive influence on the extent of usage of soil conservation practices among the farmers. It is therefore recommended that root and tuber expansion programme should be strengthened and expanded to other communities that have not benefited from the programme. Also, extension agents should lay more emphasis or intensify more effort in conducting educational programmes and training courses for farmers on best soil conservation practices so as to be more familiar with improved soil management that will improve their productivity and livelihood. 


\section{REFERENCES}

Adediran, David (2008). Effect of livelihood diversification on socio-economic status of rural dweller in Ogun State, Nigeria. M.Sc, thesis, unpublished, Ibadan: University of Ibadan

Adefalu, L.L, Ogunlade, I, Oladipo, F.O and Adeyemo, M.A.(2010\& 2011): Youth Development Agents' Needs: Challenges for Extension Volunteer Management Competencies in Nigeria Agrosearch (2010 \& 20011) 11 No. $1 \& 269-82$.

Birte Junge, Robert Abaidoo, David Chikoye, and Karl Stahr (2008). Soil Conservation in Nigeria: Past and Present On-Station and On-Farm Initiatives. Soil and water conservation society, $431 \mathrm{pp}$.

Daudu, A.K., (2016). Gender Involvement in Soil Fertility Management Practices among Smallholder Arable Crop Farmers in Kwara State, Nigeria. An unpublished Ph.D. Agric. Extension Thesis in the Department of Agricultural Extension and Rural Development, University of llorin, llorin, Nigeria, pp: 46-48.

FAO (2013). What is Conservation Agriculture? http://www. fao.org/ag/ca/1a.html.

Federal Republic of Nigeria (2007). Official Gazette: Legal Notice on publication of the details of the breakdown of the National and State provisional totals 2006 Census. Government Notice Nr 21. Nr. 24. Vol. 94. Sustainable Food Security, Improved Nutrition, Wealth Creation and Environmental Conservation in Africa. Proceedings of 9th ISTRC-AB Symposium, Mombasa, Kenya, 1-5 November 2004.

IFPRI, (2007). Food safety in the cgiarifpri-cgiar Science Council Roundtable on Food D.F. Acton, D. Richard Coote, W. Eilers 2013.Soil Conservation. The Canadian Encyclopedia

Lekwa, G. and Whiteside E.P (1996): Coastal plain sand of southeastern Nigeria. Soil science society of American Journals, 50 pp 154-160.

Matanmi B.M., Adesiji G. B, Olasheinde E. M., And Oladipo F. O. (2011): Assessment of usage of upgraded indigenous shea butter processing Technology by women processors in Kwara State, Nigeria, Agrosearch 11(1\&2) 19 - 30 Http://dx.doi.org/10.4314/agrosh.v11i1.3

Mendola (2007): Indigenous technology Adoption and Poverty Reduction in Rural Nigeria. 
NPC (2006): National Population Census, Abuja, Nigeria.

Onwudike, S.U, Uzoho, B.U., Ihem, E.E, Ahukaemere, C.M., Nkwopara, U., Irokwe, I. F., and Echeanyanwu, G.I (2016): Evaluation of the Fertility Status of selected Soils in Mbaise, Imo State Southeastern Nigeria using Nutrient Index Method. Agrosearch (2016) 16 No. 175 - 86 http://dx.doi.org/10.4314/agrosh.v16i1.7 